\title{
The Effect Of Health Education On Princess Adolescent Anniversary In Dealing With Menache
}

\author{
Edison Siringoringo ${ }^{1}$, Selviani $^{2}$, Nurlina $^{3}$ \\ ${ }^{1}$ Department of Nursing, Stikes Panrita Husada Bulukumba, Indonesia \\ ${ }^{2}$ Nursing Student Program, Stikes Panrita Husada Bulukumba,Indonesia \\ ${ }^{3}$ Department of Nursing, Stikes Panrita Husada Bulukumba, Indonesia
}

\section{Corresponding author: Edison Siringoringo}

Email: edi.siringoringo@gmail.com

\begin{abstract}
Anxiety is a state of mood marked by negative effects and symptoms of physical tension symptoms in which a person anticipates the possibility of danger or misfortune in the future with feelings of worry, anxiety may involve feelings, behaviors, and physiological responses. The aim is to determine the effect of health education on the level of anxiety of young women in dealing with menarche in Smp Negeri 9 Bulukumba. The method used in this study is to use a pre-experiment approach to post-test control group design. Without using a control group. The study is to use a pre-experimental design with a pro-test post-test control group design approach without using a control group. The result of this study is based on the results of statistical tests with Mc Nemar hypothesis test with a significance level of $95 \%$ obtained P-value $=0,000(p<0,05)$, So Ha is accepted then it can be stated there is an influence of health education on the level of anxiety of young women in dealing with menarche in Smp Negeri 9 Bulukumba. Conclusions and suggestions there is the influence of health education on the level of anxiety of young women in dealing with menarche in-state junior high school 9 Bulukumba in 2019.
\end{abstract}

Keyword: Menarche, Anxiety Level 


\section{PENDAHULUAN}

Masa remaja merupakan masa peralihan dari masa kanak-kanak ke masa dewasa yang meliputi semua perkembangan seperti perkembangan fisik, emosional, maupun sosial yang akan dialami remaja putri sebagai proses persiapan memasuki masa dewasa (sundari,2014). Menarche merupakan menstruasi pertama yang biasanya terjadi dalam rentang usia 10-16 tahun atau pada masa awal remaja di tengah pubertas sebelum memasuki masa reproduksi (Proverawati dan Misroh,2011). Di indonesia gadis remaja pada waktu menarche bervariasi antara 10-16 tahun dan rata-rata menarche 12,5 tahun, usia menarche lebih dini di daerah perkotaan dari pada yang tinggal di desa dan juga lebih lambat wanita yang kerja berat (Wilnjosastro,2012). Menstruasi adalah suatu peristiwa baru yang dapat menyebabkan seseorang remaja putri stress atau karna perubahan negatif lain. Pada umumnya gejala yang timbul pada saat haid pertama kali (menarche), yaitu kecemasan atau ketakutan yang di perkuat dengan keinginan keinginan untuk menolak proses fisiologi. Maka banyak peristiwa menstruasi pertama dihayati sebagai suatu pengalaman traumatis (Yetty,2010).

Hasil penelitian (Kusmiran,2012), Pengaruh Pendidikan Kesehatan tentang Menstruasi terhadap Tingkat Pengetahuan dan Kecemasan menghadapi Menarche pada siswi kelas IV dan V SD Negeri bantul Yogyakarta, didapatkan pengetahuan siswi tentang menstruasi sebelum di berikan pendidikan dan sesudah perlakuan ada peningkatan dengan nilai $\quad \mathrm{p}=$ 0,001. Survei Demografi dan Kesehatan Indonesia (SDKI) 2012 umur 15-24 tahun yang sudah haid, mendiskusikan dengan orang lain tentang haid sebelum mereka mengalami haid yang pertama, persentase orang yang di ajak diskusi tengtang haid dengan teman $(53,6 \%)$, dengan guru 13,5\% dan satu dari empat wanita tidak mendiskusikan tentang haid dengan orang lain sebelum mengalami haid yang pertama. Dalam jurnal yang terkait yaitu ''Hubungan Pengetahuan Dengan Sikap Remaja Putri Dalam Menghadapi menarche Di Smpn 2 Biau Kabupaten Buol. Berdasarkan hasil riset kesehatan dasar tahun 2010 sebanyak 5,2\% anak anak di 17 provinsi di Indonesia telah memasuki usia menarche di bawah usia 12 tahun. Membaiknya standar kehidupan berdampak pada penurunan usia menarche ke usia yang lebih mudah (Muryati,2012) Rata - rata perempuan di sumatra barat mengawali usia reproduksi pada umur 13 tahun,. (Depkes RI 2011). Data hasil penelitian pada salah satu SMP di Kota padang usia menarche lebih dini dari 12,5 tahun menjadi 11,5 tahun (Susanti,2012). Tujuan penelitian ini Untuk Mengetahui tingkat kecemasan remaja putri di SMP Negeri 9 bulukumba dalam menghadapi menarche. 


\section{BAHAN DAN METODE}

\section{Desain Penelitian}

Jenis penelitian ini adalah Penelitian ini menggunakan desain Pra-Eksperiment dengan pendekatan Pre-test Post-test controlGroupdesign. (Notoadmodjo,2013).

\section{Populasi dan Sampel}

Populasi merupakan seluruh subjek atau objek dengan karakteristik tertentu yang akan diteliti, bukan hanya objek atau subjek uang dipelajari saja tetapi seluruh karakteristik atau sifat yang dimiliki subjek atau objek tertentu (Hidayat, 2018). Populasi dalam penelitian ini adalah siswi Smp Negeri 9 Bulukumba Sebanyak 60 orang.

Teknik sampel pada penelitian ini menggunakan Cara pengambilan sampel dengan cara Non probability Sampling dengan teknik sampel quota sampling. Yaitu sebanyak 100 siswa di kelas VII dimana diantaranya terdapat 40 remaja putra dan 60 remaja putri dimana dari 60 remaja putri tersebut, 27 diantaranya sudah menstruasi, dan 3 remaja putri merasa biasa saja menghadapi menarche, dan 30 merasa cemas dan khawatir menghadapi menarche.

\section{Instrumen Pengumpulan Data}

Instrumen peneitian adalah suatu alat yang di gunakan oleh peneliti untuk mengobservasi, mengukur atau menilai suatu fenomena. Data yang di peroleh dari suatu pengukuran kemudian dianalisis dan dijadikan sebagai bukti dari suatu penelitian (Dharma 2011). Instrumen yang digunakan pada penelitian dengan pendidikan kesehatan berupa SAP (satuan acara penyuluhan) dan instrumen pada penelitian tingkat kecemasa adalah instrumen dalam bentuk kuesioner yang di adopsi menurut (HARS-A). Yang terdiri dari 14 pernyataan setiap jawaban dari pernyataan diberi nilai 4 = gejala berat sekali, $3=$ gejala berat, $2=$ gejala sedang, 1 = gejala ringan dan o = tidak ada gejala. Kuesioner adalah suatu bentuk atau dokumen yang berisi beberapa pertanyaan atau pernyataan yang dibuat berdasarkan indikator - indikator suatu variabel (Dharma 2011). Instrumen dalam penelitian ini adalah berupa kuesioner untuk tingkat kecemasan dan Media berupa lembar poto copy untuk pendidikan kesehatan.

\section{Analisis Data}

Data diuji menggunakan Uji bivariat menggunakan rumus uji Mc.Nemar, jika data berdistribusi normal dan jika nilai probabilitas signifikasi $>0,05$ maka tidak terdapat perbedaan yang signifikan, sebaliknya jika nilai probabilitas signifikasi $<0,05$ maka terdapat perbedaan yang signifikan. 


\section{HASIL}

Berdasarkan tabel 1 menunjukan bahwa distribusi responden yang terbanyak pada umur 13 tahun didapatkan 17 orang (56.7\%) dan yang berumur 12 tahun sebanyak 4 orang (13.3\%).

Tabel.1 Distribusi frekuensi responden berdasarkan umur

\begin{tabular}{ccc}
\hline Klasifikasi Umur & Frekuensi (n) & Persentase (\%) \\
\hline 12 & 4 & 13.3 \\
13 & 17 & 56.7 \\
14 & 9 & 30.0 \\
\hline Total & $\mathbf{3 0}$ & $\mathbf{1 0 0}$ \\
\hline
\end{tabular}

Berdasarkan tabel 2 menunjukan bahwa responden yang mengalami tingkat kecemasan sebelum (Pre) dilakukan penyuluhan didapatkan cemas sebanyak 22 orang $(73,3 \%)$ dikarnakan siswi tersebut tidak tau dan tidak mengerti apa itu menarche, kurangnya informasi membuat siswi tersebut merasa cemas dan yang tidak cemas sebanyak 8 orang(26,7\%) siswi yang tidak cemas tersebut adalah siswi yang sudah haid dan mengetahui apa itu menarche.

Tabel 2.Distribusi frekuensi responden berdasarkan tingkat kecemasan (Pre)

\begin{tabular}{ccc}
\hline Tingkat kecemasan (PRE) & Frekuensi (f) & Persentase (\%) \\
\hline Cemas & 22 & 73.3 \\
Tdk cemas & 8 & 26.7 \\
\hline Total & $\mathbf{3 0}$ & $\mathbf{1 0 0}$ \\
\hline
\end{tabular}

Berdasarkan Tabel 3 menunjukkan responden yang tidak mengalami tingkat kecemasan sesudah (Post) diberi penyuluhan didapatkan tidak cemas sebanyak 25 orang $(83,3 \%)$ karna siswi sudah mampu dan mengetahui resiko yang ditimbulkan apabila mengalai menarche dan mengalami cemas sebanyak 5 orang $(16,7 \%)$ dari 25 siswa yang sudah tidak cemas masih ada 5 orang yg cemas setelah dilakukan penyuluhan dikarnakan siswi tersebut belum tau dan tidak mengerti apa itu menarche masih berusia 12 tahun.

Tabel 3.Distribusi frekuensi responden berdasarkan tingkat kecemasan (post)

\begin{tabular}{ccc}
\hline Tingkat kecemasan (POST) & Frekuensi (n) & Persentase (\%) \\
\hline Cemas & 5 & 16.7 \\
Tidak cemas & 25 & 83.3 \\
\hline Total & $\mathbf{3 0}$ & $\mathbf{1 0 0}$ \\
\hline
\end{tabular}

Berdasarkan hasil uji stastistik dengan uji hipotesis Mc Nemar dengan derajat kemaknaan $95 \%$, diperoleh $p$ value $=0,000(p<0,05)$, sehingga Ha diterima, maka dapat dinyatakan 
terdapat pengaruh pendidikan kesehatan terhadap tingkat kecemasan remaja putri dalam menghadapi menarche di SMP Negeri 9 Bulukumba.

Tabel 4. Hasil Uji Mc.Nemar

\begin{tabular}{|c|c|c|c|}
\hline \multirow{2}{*}{ Pre } & \multicolumn{2}{|c|}{ Post } & \multirow[t]{2}{*}{ P Value } \\
\hline & Cemas & Tdk Cemas & \\
\hline Cemas & 5 & 17 & 0,000 \\
\hline Tdk Cemas & 0 & 8 & \\
\hline
\end{tabular}

\section{PEMBAHASAN}

Berdasarkan hasil penelitian yang dilakukan menunjukkan bahwa dapat diketahui yang mengalami kecemasan sebanyak 22 orang (73,3\%), sedangkan yang tidak mengalami kecemasan sebanyak 8 orang $(26,7 \%)$. Berdasarkan hal ini sejalan dengan penelitian yang dilakukan oleh Sudjana yang menyatakan bahwa sebelum diberikan pendidikan kesehatan tingkat kecemasan berada pada kategori ringan yaitu $(51,7 \%)$. Kecemasan adalah suatu perasaan yang timbul ketika seseorang terlalu menghawatirkan kemungkinan terjadinya peristiwa yang menakutkan yang akan terjadi di masa depan .

Menurut asumsi peneliti melihat adanya efek negative dari kecemasan yang dapat membawa kerugian bagi setiap yang mengalaminya, maka perlu adanya pendidikan kesehatan tentang menarche. Berdasarkan hasil penelitian yang dilakukan menunjukkan bahwa setelah dilakukan penyuluhan pendidikan kesehatan ada penurunan dimana yang tidak mengalami kecemasan sebanyak 25 orang $(83,3 \%)$ dan yang mengalami kecemasan sebanyak 5 orang (16,7\%). Kecemasan adalah gangguan alam perasaan yang ditandai dengan perasaan ketakutan atau kekawatiran yang mendalam dan berkelanjutan, tidak mengalami gangguan dalam menilai realitas (Reality testing Ability/RTA), kepribadian masih utuh, perilaku dapat terganggu tetapi dalam batas - batas normal (Hawari, 2013). Kecemasan menghadapi menarche juga memengaruhi kondisi sosial remaja putri.Hal ini dapat dibuktikan dari hasil penelitin pada remaja putri di istambul merasakan cemas, takut dan menangis pada saat mengalami menarche yang mengakibatkan murung, ingin menyembunyikan kalau mereka sudah mendapat haid pertama kepada orang lain (Karoc etall, 2014), sehingga apabila masalah kecemasan menghadapi menarche banyak terjadi dan tidak diperhatikan, hal ini juga merupakan masalah kesehatan masyarakat.

Penelitian ini sejalan dengan penelitian yang dilakukan oleh winarti, 2017 dengan judul penelitian pengaruh pendidikan kesehatan terhadap kecemasan tentang menarche pada siswi kelas V sekolah dasar hasil dalam penelitian ini juga menjelaskan gejalah yang sering muncul 
diantaranya merasakan cemas, takut dan menangis pada saat mengalami menarche yang mengakibatkan murung, ingin menyembunyikan kalau mereka sudah mendapat haid pertama kepada orang lain. Menurut asumsi peneliti, ditemukannya sebagian besar responden yang memiliki tingkat kecemasan berat dan sedang mengalami penurunan menjadi kecemasan ringan dan yang tidak mengalami kecemasan dikarnakan oleh pemberian pendidikan kesehatan tentang menarche.

\section{KESIMPULAN DAN SARAN}

Berdasarkan hasil penelitian diatas maka disimpulkan bahwa terdapat hubungan proporsi antara pendidikan kezsehatan dan tingkat kecemasan remaja putri dalam menghadapi menarche di smp negeri 9 bulukumba.

Hasil penelitian inihendaknya dijadikan pedoman dapat dijadikan sebagai bahan masukan pada siswa khususnya tentang pengaruh pendidikan kesehatan terhadap tingkat kecemasan remaja putri dalam menghadapi menarche di Smp Negeri 9 Bulukumba Tahun 2019.

\section{DAFTAR PUSTAKA}

Ah, Y. et al. (2017) Kebutuhan Spiritual: Konsep dan Aplikasi dalam Asuhan Keperawatan. Jakarta: Mitra Wacana Media.

Dahlan, M.S. (2011) Langkah-langkah Membuat Proposal Penelitian Bidang Kedokteran dan Kesehatan. 2nd edn. Jakarta: Sagung Seto.

Dharma, K.K. (2011) Metodologi Penelitian Keperawatan (Panduan Melaksanakan dan Menerapkan Hasil Penelitian). Edisi Revi. Jakarta: TIM.

Direktorat Jendral Pemasyarakatan (2018) Sistem Database Pemasyarakatan, Indonesia. Availableat:

http://smslap.ditjenpas.go.id/public/grl/current/monthly/year/2018/month/12 (Accessed: 31 December 2018).

Faizin, M.C. (2016) Hubungan Antara Intensitas Dzikir Dengan Optimisme Kesembuhan Pada Pecandu Narkoba Di Pondok Rehabilitasi, Jurnal Ilmiah Psikologi, (Skripsi).

Gunawan, I. \& Yahya (2016) Pelatihan Kaligrafi Terhadap Tingkat Stress Narapidana, Jurnal Psikoislamika, (Skripsi).

Hidayat, A.A.A. (2018) Metodologi Penelitian Keperawatan dan Kesehatan. Jakarta: Salemba Medika.

Nasir, A. \& Muhith, A. (2011) Dasar-Dasar keperawatan Jiwa: Pengantar Dan Teori. Jakarta: Salemba Medika. 
Nilamastuti, M.T. (2016) Hubungan Tingkat Spiritual dengan Tingkat Stres Pada Narapidana di Lembaga Permasyarakatan Kelas IIA Kabupaten Jember (Skripsi).

Rachwati, H. (2019) Hubungan Tingkat Spiritual Dengan Tingkat Stres Pada Narapidana Di Lembaga Pemasyarakatan Kelas II B Kota Mojokerto, Jurnal Penelitian STIKES Bina Sehat PPNI Mojokerto(Skripsi).

Riskesdas (2018) Hasil Utama Riskesdas 2018 : Kementrian Kesehatan Badan Penelitian dan Pengembangan Kesehatan.

Available at: http://www.depkes.go.id/resources/download/info-terkini/materi_rakorpop_2018/Hasil Riskesdas 2018.pdf.

WHO (2017) Depression and Other Common Mental Disorders: Global Health Estimates. Available at: https://apps.who.int/iris/bitstream/handle/10665/254610/WHO-MSDMER-2017.2eng.pdf;jsessionid=887A853057D51507C5E919E0DEA2E83F?sequence=1. 